Canadian University Music Review

Revue de musique des universités canadiennes

\title{
Introduction to the Occasional Conference, "The Sociology of Music: An Exploration of Issues," Held at Peter Robinson College, Trent University, Peterborough, Ontario, August 4-6, 1983
}

\section{John Shepherd}

Numéro 5, 1984

URI : https://id.erudit.org/iderudit/1013927ar

DOI : https://doi.org/10.7202/1013927ar

Aller au sommaire du numéro

Éditeur(s)

Canadian University Music Society / Société de musique des universités canadiennes

ISSN

0710-0353 (imprimé)

2291-2436 (numérique)

Découvrir la revue

Citer ce document

Shepherd, J. (1984). Introduction to the Occasional Conference, "The Sociology of Music: An Exploration of Issues," Held at Peter Robinson College, Trent

University, Peterborough, Ontario, August 4-6, 1983. Canadian University Music Review / Revue de musique des universités canadiennes, (5), xi-xiv.

https://doi.org/10.7202/1013927ar

All Rights Reserved (C Canadian University Music Society / Société de musique des universités canadiennes, 1984
Ce document est protégé par la loi sur le droit d'auteur. L'utilisation des services d'Érudit (y compris la reproduction) est assujettie à sa politique d'utilisation que vous pouvez consulter en ligne.

https://apropos.erudit.org/fr/usagers/politique-dutilisation/ 


\section{INTRODUCTION TO THE OCCASIONAL CONFERENCE, "THE SOCIOLOGY OF MUSIC: AN EXPLORATION OF ISSUES," HELD AT PETER ROBINSON COLLEGE, TRENT UNIVERSITY, PETERBOROUGH, ONTARIO, AUGUST 4-6, 1983}

To say that musical structures, musical processes and musical textures are in some way reflective of the culture and society in which they are created is to make a claim that most historical musicologists would find unexceptional and unobjectionable. However, to follow through on this claim, to explore systematically and rigorously the precise nature of the relationships between musical and social processes has been to engage in a task that is not only difficult intellectually but that has evoked resistance from within the hallowed halls of conventional musicology. To persist in this task from a critical perspective, with a mind open to the possibility that established wisdoms concerning the value and aesthetic acceptability of different musical styles are not beyond question has been to verge on the scandalous. As Christopher Ballantine recently remarked:

At a time when remarkable headway has been made in the development of Marxist aesthetics in other areas of artistic production (literature, painting and cinema, for example), one of the greatest obstacles in the way of the creation of a Marxist musical aesthetics is the obdurate hegemony of a bourgeois professional musical elite in all forums where "classical" music is produced, taught, researched, theorized, or reproduced. So total is this hegemony that it is nearly impossible in the corridors of its influence to sustain the view that a different conceptualization of music could even be thought. A condition of one-dimensionality is here thoroughly installed: attempts to challenge and confront it produce a kind of scandal, if they are heard at all (Ballantine 1984: xviii).

These are harsh words. Yet they should be taken seriously, not only because they ring true in the ears of those who have worked to bring about alternative musicologies, but more importantly, because they come from the pen of a scholar with an enviable record of publications in recognized musicology journals. The malaise has been acknowledged from within. 
Something is clearly at stake. There is little doubt that mainstream sociology, particularly as it is practised in North America, is bankrupt where the arts and culture are concerned. Models of society that blueprint the individual will always encounter difficulties in teasing out the social and cultural processes which breath the very life, the very creativity into individual artifacts. If people are essentially social animals, then they are so in ways that are active rather than passive. Failing to recognize this, conventional sociology can, in the words of Howard S. Becker, do little more than "claim the domain of the arts for sociology in return for a promissory note for an analysis to be delivered, if all goes well, on some later occasion." As Becker concludes, "sociologists have left so many of these obligations unredeemed that artists and humanistic scholars have become justifiably wary of their pretensions" (Becker 1977: xiii).

Musicians and musicologists have every right, therefore, to be wary of sociological approaches that would squeeze the life out of music, see it purely as "social function," and so deny its very musicality. However, to argue that musical processes are social processes is not, inevitably, to lead to this consequence in the understanding of musical life and musical creativity. There are schools of sociology, cultural anthropology, semiology, and structuralism that stress the centrality of individuals in creating and shaping the social world, that is, life and reality itself, through various symbolic systems including that of "music." When the power of music to actively shape our lives is more securely grasped, it may then be possible to move more successfully than hitherto in releasing much music from its present position of bondage, either as the "cultural capital" of those with power and influence, or as "ephemeral trivia," relegated to the "inconsequential" status of entertainment and leisure.

The purpose of the Trent Conference was to raise the issues implicit in undertaking a sociology of music, to highlight the area as deserving more attention than it presently receives from the academic world, to bring together scholars in Canada interested in the field, and to make them aware not only of each others' work but the work also of major figures outside Canada. The Conference was judged successful in these aims by those who attended. Some twenty-four papers were given by twenty-seven presenters from Canada, Sweden, the United Kingdom, and the 
United States of America. It was possible for the many Canadian graduate students who attended the Conference and gave papers to discuss their work and topics of mutual interest with scholars such as Steven Feld, Simon Frith, Charles Keil, Philip Tagg, and Graham Vulliamy - scholars who have made and are currently making important contributions to the understanding of music as a cultural and social phenomenon.

The papers in this issue do not attempt to be representative of the Conference as a whole. Sessions were held on Sociomusicological Theory, The Sociological Analysis of Musical Forms, Definitions and Legitimations of Music, Contemporary Subcultural Music, The Sociology of Punk, the Sociology of Music Education, and Music and the Environment. Given constraints related to space and availability of papers, the seven included here should be regarded simply as an illustration of the diverse topics aired and discussed at the Conference. Jan Ling's paper is a useful historical survey of the field of the sociology of music, with particular emphasis on work in Sweden and the German-speaking and East European worlds. Graham Vulliamy critically summarizes extant work in the sociology of music education, while Harry Haughton, in work extracted from his Ed.D. dissertation makes important connections between stateinfluenced processes of social and cultural reproduction and the views and attitudes of those concerned with music education on a day-to-day basis. Chris McCormick, in a paper based largely on content analysis, discusses the ways in which Maritime folk song both reflects and contributes to the lives of people in that part of Canada. Continuing the focus on Canada, Lynn Whidden engages in an informal analysis of the aesthetic reasons underlying the predilection of many native poeples for country music. Will Straw's paper is a perceptive study of the processes through which Heavy Metal cultures create and maintain largely ahistorical and socially distanced world views and self-images. Finally, Howard Broomfield discusses the composition of In Doig People's Ears, a juxtaposition of sound-scape materials designed to create a feel for the history of the Beaver Indian people.

It became clear from the Conference that a surprising level of work is underway in Canada in the sociology of music. There was also strong feeling that the Conference should be continued as a regular event in the Canadian academic calendar. That aim was recently furthered through a two-day International Con- 
ference on "Popular Music in the University" held at Carleton University, March 29-30, 1985. I hope that the papers in this issue will be of interest to readers of this journal as evidence of both the amount and level of work presently carried out largely by scholars other than historical musicologists whose inclusion in the research and teaching programs of music departments could hardly help but enliven and enrich the curriculum.

The Conference was sponsored by The Cultural Studies Programme, Trent University, The Canadian Branch of the International Association for the Study of Popular Music, and the Trent Institute for the Study of Popular Culture. It was made possible through the financial support of The Social Sciences and Humanities Research Council of Canada, The T.E.W. Nind Endowment Trust Fund, Trent University, and The Cultural Studies Programme, Trent University. The assistance of Jody Berland, Costas Boundas, Ian McLachlan, and Andrew Wernick in organizing the Conference is also gratefully acknowledged.

John Shepherd Department of Music Carleton University

\section{REFERENCES}

BALLANTINE, C.

1984: Music and its Social Meanings. New York: Gordon and Beach.

BECKER, H.S.

1977: "Preface", in Shepherd, J., Virden, P., Vulliamy, G., and Wishart, T., Whose Music? A Sociology of Musical Languages. London: Latimer New Dimensions; reprinted New Brunswick, N.J.: Transaction Books, 1980. 